\title{
HUBUNGAN KUALITAS DAN LOYALITAS NASABAH JASA PERBANKAN \\ PT. BANK RAKYAT INDONESIA (PERSERO), TbK KOTA MEDAN
}

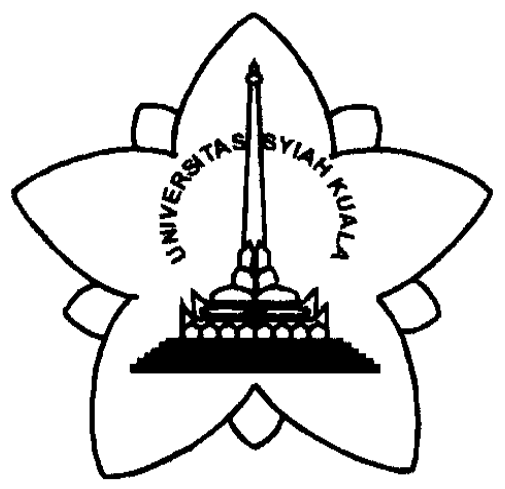

Oleh :

\section{DEDY ANSARI HARAHAP \\ NIM : 0492020173}




\section{PENGESAHAN KOMISI PEMBIMBING}

Dengan ini dinyatakan bahwa kami pembimbing telah membaca Karya Ilmiah dengan Judul “ HUBUNGAN KUALITAS DAN LOYALITAS NASABAH JASA PERBANKAN PT. BANK RAKYAT INDONESIA (PERSERO), Tbk KOTA MEDAN" oleh Dedy Ansari Harahap NIM 0292020173 untuk diketahui oleh Ketua Program Studi dan setuju diajukan kepada Panitia Komisi Ujian Program Studi Magister Managemen Program Pasca Sarjana Universitas Syiah Kuala- Darussalam Banda Aceh

\section{Menyetujui :}

Pembimbing Utama

$\frac{\text { Dr. Jasman J. Ma'ruf, SE, MBA }}{\text { Nip. }}$ Nip. 131671755
Pembimbing Pembantu

Drs. Miftahuddin, MM Nip. 131698715

Dr. Jasman J. Ma'ruf, SE, MBA

Nip : 131671755 


\title{
PENGESAHAN KOMISI UJIAN
}

\author{
Karya Akhir Berjudul \\ HUBUNGAN KUALITAS DAN LOYALITAS NASABAH JASA \\ PERBANKAN PT. BANK RAKYAT INDONESIA (PERSERO), TbK \\ KOTA MEDAN
}

Yang dipersiapkan dan disusun oleh :

\section{DEDY ANSARI HARAHAP \\ NIM: 0292020173}

Konsentrasi : Manajemen Pemasaran

Telah dipertahankan didepan Panitia Komisi Ujian Program Magister Manajemen Program Pasca Sarjana Universitas Syiah Kuala pada tanggal 19 Juli 2006 dan dinyatakan telah memenuhi syarat untuk diterima.

\section{Panitia Komisi Ujian}

\begin{tabular}{|c|c|}
\hline$\frac{\text { Prof. T.A. Hamid, MAB }}{\text { NIP : } 130214589}$ & Ketua \\
\hline$\frac{\text { Dr. Jasman J. Ma'ruf, SE, MBA }}{\text { NIP : } 131671755}$ & Sekretaris \\
\hline$\frac{\text { Drs. Miftahuddin, MM }}{\text { NIP : } 131698715}$ & Anggota \\
\hline$\frac{\text { Drs. Fachrurrazi Zamzami, MBA }}{\text { NIP : } 130364977}$ & Anggota \\
\hline$\frac{\text { Drs. Sofyan Idris, MBA }}{\text { NIP : } 131671753}$ & Anggota \\
\hline
\end{tabular}

\author{
Darussalam, 19 Juli 2006 \\ Program Pasca Sarjana Universitas Syiah Kuala \\ Direktur,
}

Prof. Dr. Chairul Ichsan, M.Sc

Nip : 130515917 


\section{KATA PENGANTAR}

Puji Syukur kami persembahkan kehadirat ALLAH SWT atas Rahmat dan Hidayat-NYA, penulis dapat menyelesaikan Karya Akhir ini yang merupakan salah satu syarat yang harus dipenuhi sebelum mengikuti ujian akhir dan sebagai berakhirnya kegiatan perkuliahan bagi Mahasiswa.

Karya akhir Tesis dengan Judul "HUBUNGAN KUALITAS DAN LOYALITAS NASABAH JASA PERBANKAN PT. BANK RAKYAT INDONESIA (PERSERO), Tbk KOTA MEDAN" hal ini dimaksudkan untuk dapat melihat hubungan kualitas dan loyalitas jasa perbankan PT. Bank Rakyat Indonesia (Persero), Tbk di Kota Medan.

Dalam penulisan Karya Akhir ini tentu saja tidak terlepas dari bantuan berbagai pihak yang telah banyak membantu, memberikan dorongan, saran dan semangat, dimana dalam kesempatan ini penulis mengucapkan terima kasih yang sebesar-besarnya dan juga penghargaan yang setinggi-tingginya kepada sbb :

1. DR. Jasman J. Ma'ruf, SE. MBA, selaku Ketua Program Studi Magister Manajemen Universitas Syiah Kuala Banda Aceh dan dosen yang telah banyak memberikan materi ilmiah yang cukup bermanfaat bagi terwujudnya penulisan proposal ini.

2. DR. Jasman J. Ma'ruf, SE. MBA, selaku Pembimbing Utama dan sebagai Dosen yang telah banyak memberikan materi ilmiah selama masa perkuliahan sampai terwujudnya penulisan proposal ini.

3. Drs. Miftahuddin MM, selaku Pembimbing Pembantu, dan sebagai Dosen yang telah banyak memberikan materi ilmiah, arahan, masukan selama perkuliahan sampai terwujudnya penulisan proposal ini.

4. Bapak / Ibu Dosen, staf pengajar maupun pegawai, karyawan/ti pada Program Studi Magister Manajemen Universitas Syiah Kuala Banda Aceh dan Unimed Medan, yang telah banyak membantu kami baik dalam perkuliahan maupun dalam hal administrasi bagi mahasiswa sehingga terwujud dan lancarnya penulisan Karya Akhir ini. 
5. Kepada kedua Orang Tua, Isteri tercinta Dita Amanah, MBA serta anggota keluarga lain yang tidak henti-hentinya memberikan dukungan baik moril maupun materil dan selalu mendoakan agar sehat selalu dalam mengikuti perkuliahan dan kemampuan dalam menyelesaikannya.

6. Bapak Pimpinan Cabang PT. Bank Rakyat Indonesia (Persero), Tbk kota Medan di 3 (tiga) kantor cabang yang ada di Medan yang telah banyak memberikan bantuan sehingga dapat menyelesaikan kuliah dan karya akhir ini.

7. Semua Mahasiswa Angkatan XXXVIII tahun 2004 pada Program Studi Magister Manajemen Universitas Syiah Kuala Banda Aceh yang telah banyak membantu saya sejak perkuliahan sampai dengan penulisan karya akhir ini.

8. Semua Nasabah PT. BRI (Persero), Tbk Kota Medan yang telah banyak membantu dalam memberikan data-data, masukan, saran, mengedarkan Kuisioner kepada Badan Usaha.

Akhirnya dengan segala kerendahan hati penulis berharap agar karya akhir ini dapat bermanfaat bagi penulis sendiri dan pengembangan ilmu pengetahuan khususnya dalam bidang pemasaran bagi teman-teman pada PT. BRI (Persero),Tbk Kota Medan, yang akan melanjutkan penelitian-penelitian sejenis. Penulis juga menyadari bahwa dalam penyelesaian Karya Akhir ini banyak sekali kekurangan-kekurangan maupun kelemahan-kelemahan, baik dalam teori maupun dalam paparannya. Untuk itu penulis berharap agar para pembaca dapat memakluminya dan memberikan saran dan kritikan yang berguna bagi kesempurnaan karya akhir ini untuk masa mendatang. Amiin.

Darussalam, Juli 2006

Penulis

\section{DEDY ANSARI HARAHAP}

Program Studi Magister Manajemen Program Pascasarjana

Universitas Syah Kuala Nangroe Aceh Darussalam 


\author{
ABSTRAK \\ Abstrak Karya Akhir diserahkan kepada Panitia Komisi Ujian untuk \\ mendapatkan Gelar Magister Manajemen pada Program Studi \\ Magister Managemen Program Pasca Sarjana \\ Universitas Syiah Kuala \\ HUBUNGAN KUALITAS DAN LOYALITAS NASABAH \\ JASA PERBANKAN \\ PT. BANK RAKYAT INDONESIA (PERSERO), TbK \\ KOTA MEDAN
}

oleh

\title{
DEDY ANSARI HARAHAP
}

NIM : 0492020173

Konsentrasi Manajemen Pemasaran

$\begin{array}{lll}\text { Pembimbing Utama } & : & \text { Dr. Jasman J. Ma'ruf, SE, MBA } \\ \text { Pembimbing Pembantu } & : & \text { Drs. Miftahuddin, MM }\end{array}$

Tujuan penelitian ini adalah untuk mengetahui hubungan kualitas jasa dan loyalitas nasabah pada PT. Bank Rakyat Indonesia (Persero), Tbk Kota Medan. Sebanyak 210 orang responden telah dipilih secara kluster sebagai sampel. Data diperoleh dengan mengedarkan angket kepada seluruh responden. Data yang diperoleh adalah valid dan dapat dipercaya dengan persyaratan statistik yang telah ditetapkan. Hal ini dapat dilihat dari nilai alpha sebesar 0,920 untuk reliabilitas variabel kualitas dan 0,536 untuk variabel loyalitas.

Kontribusi semua faktor yang diteliti menunjukkan adanya hubungan yang signifikan antara kualitas dan loyalitas nasabah jasa perbankan PT. Bank Rakyat Indonesia (Persero), Tbk Kota Medan. Hal ini diperoleh dengan menggunakan uji korelasi bivariat dengan hasil 0,000 yaitu nilai yang berada dibawah 0,05. Jadi, secara keseluruhan terdapat hubungan signifikan antara kedua variabel tersebut (kualitas dan loyalitas).

Hasil penelitian memperlihatkan bahwa koefisien korelasi antara variabel kualitas dan loyalitas sebesar 0,611 yang berarti bahwa terdapat hubungan diantara kedua variable tersebut. Hal ini juga dapat dilihat dari korelasi pearson diantara kedua variabel tersebut dengan tingkat hubungan sebesar 0,651. Jadi secara keseluruhan hasil penelitian ini memperlihatkan adanya hubungan yang signifikan antara variabel kualitas dan loyalitas nasabah jasa perbankan PT. Bank Rakyat Indonesia (Persero), Tbk Kota Medan. Hasil penelitian menunjukkan bahwa terdapat hubungan yang signifikan antara kualitas dan loyalitas nasabah jasa perbankan PT. Bank Rakyat Indonesia (Persero), Tbk Kota Medan. 


\begin{abstract}
Abstract of the final paper submitted to the Examination Commitee in partial fulfillment of the requerement for the Degree Master of Management on the Graduated Program Syiah Kuala University.

\section{RELATIONSHIP SERVICE QUALITY AND CUSTOMER LOYALTY PT. BANK RAKYAT INDONESIA ( PERSERO), Tbk IN MEDAN CITY}

\author{
By \\ DEDY ANSARI HARAHAP \\ SN : 0492020173 \\ Specialisation : Marketing Management \\ Supervisor : Dr. Jasman J. Ma'ruf, SE, MBA \\ Co-Supervisor : Drs. Miftahuddin, MM
}

The purpose of this study is to determine the relationship between service quality and customer loyalty at PT. Bank Rakyat Indonesia (Persero), Tbk Medan City. A total of 210 respondents have been selected by cluster as sample. Data obtained by circulating questionnaires to all respondents. The data obtained is valid and can be trusted with statistical requirements that have been set. It can be seen from the alpha value of 0.920 for the reliability of the quality variable and 0.536 for the loyalty variable.

The contribution of all the factors studied indicates a significant relationship between quality and loyalty of customers of banking services of PT. Bank Rakyat Indonesia (Persero), Tbk Medan City. It is obtained by using bivariate correlation test with 0.000 result that is under 0.05 . So, overall there is a significant relationship between the two variables (quality and loyalty).

The results showed that the correlation coefficient between quality and loyalty variables of 0.611 which means that there is a relationship between the two variables. It can also be seen from the correlation of pearson between the two variables with the relationship level of 0.651 . So overall the results of this study show a significant relationship between the quality and loyalty of customers of banking services PT. Bank Rakyat Indonesia (Persero), Tbk Medan City. The results showed that there is a significant relationship between quality and loyalty of customer banking services PT. Bank Rakyat Indonesia (Persero), Tbk Medan City. 


\section{BAB I}

\section{PENDAHULUAN}

\subsection{Latar Belakang}

PT. BANK RAKYAT INDONESIA (PERSERO) Tbk, sebagai bank komersil melakukan usaha perbankan yang sehat untuk menunjang pelaksanaan pembangunan nasional dalam rangka meningkatkan pemerataan dan pertumbuhan ekonomi serta stabilitas nasional di bidang ekonomi ke arah peningkatan kesejahteraan rakyat banyak dengan tetap mengusahakan pencapaian laba yang optimal.

Pada tahun-tahun belakangan ini BRI menganalisa kembali keberhasilan/kegagalan yang dilakukan pada tahun-tahun sebelumnya dan tantangan yang ada pada masa yang akan datang. Untuk itu perlu diidentifikasi lebih awal pra kondisi yang mempengaruhi bisnis pada tahun mendatang agar dapat menghindari kegagalan yang mungkin timbul termasuk untuk menganalisis keputusan strategi yang mana yang akan diambil oleh perusahaan.

Untuk mengantisipasi persaingan yang semakin tajam dengan tantangan yang tidak sedikit, maka BRI telah menyiapkan strategi untuk menjadikannya sebagai Bank Masa Kini dan Masa Depan. Strategi itu diterapkan seraya meneruskan kebijakan umum yang telah dilaksanakan sepanjang tahun 2002 yaitu meningkatkan kualitas pelayanan nasabah dan mengembangkan program kemitraan.

Sasaran utama pemasaran produk-produk BRI bukanlah sekedar menggaet pelanggan (customer), tetapi yang lebih penting bagaimana memelihara dan Program Studi Magister Manajemen Program Pascasarjana Universitas Syah Kuala Nangroe Aceh Darussalam 
Thesis : Dedy Ansari Harahap (21 Juli 2006) Hubungan Kualitas dan Loyalitas Nasabah Jasa Perbankan

PT. Bank Rakyat Indonesia (Persero) Tbk Kota Medan

\section{9}

mempertahankan para nasabah sehingga walaupun dengan banyaknya bermunculan produk-produk pesaing (Competitor Product) yang ada di pasaran, nasabah BRI tetap loyal terhadap produk-produk BRI.

Sejak Indonesia dilanda krisis ekonomi pada tahun 1997 banyak pengusaha terpuruk dan akhirnya pailit. Oleh karena itu pengusaha mikro, kecil dan menengah perlu diberdayakan secara optimal agar usahanya dapat berkembang dan menjadi Fundamental Perekonomian Nasional. Inilah yang merupakan alasan pemilihan objek (nasabah) di dalam penelitian ini.

Kepuasan pelanggan memang diperlukan bagi kesuksesan bisnis, namun kepuasan saja tidak cukup untuk membangun atau membentuk basis pelanggan yang loyal. Pada tahun 1980-an dan 1990-an, kepuasan pelanggan merupakan semboyan bisnis. Setiap perusahaan sibuk mencari cara untuk membahagiakan pelanggan dengan memenuhi dan bahkan melebihi harapan mereka. Teorinya adalah bahwa bila para pelanggan merasa puas, mereka membeli lebih banyak dan lebih sering. Di belakang semua ini terdapat anggapan bahwa kepuasan pelanggan akan meningkatkan pendapatan, khususnya dari pembelian ulang. Tetapi ada beberapa penelitian yang menunjukkan hal yang berbeda bahwa tingkat kepuasan pelanggan yang tinggi belum tentu menghasilkan pembelian berulang dan peningkatan penjualan.

Penelitian yang dilakukan oleh Juran Institute mengungkapkan bahwa lebih dari $90 \%$ manajer puncak dari 200 lebih perusahaan terbesar Amerika setuju dengan pernyataan "upaya memaksimalkan kepuasan pelanggan juga akan memaksimumkan profitabilitas dan pangsa pasar." Walaupun demikian, dari 200 
lebih responden hanya kurang dari $2 \%$ yang mendapatkan peningkatan laba bersih dari peningkatan kepuasan pelanggan yang telah dikonfirmasikan.

Sebagian besar manajer menganggap bahwa terdapat korelasi positif antara skor kepuasan pelanggan dan perilaku membeli pelanggan. Anggapan umumnya adalah bahwa peningkatan skor kepuasan seorang pelanggan akan diikuti oleh peningkatan pangsa pendapatan yang dibelanjakan oleh pelanggan, tingkat referensi perusahaan dari pihak lain dan kerelaan pelanggan membayar pada harga yang lebih tinggi. Tetapi sebagaimana digambarkan oleh beberapa penelitian, korelasi itu tidak dapat diandalkan. Tingkat kepuasan belum tentu menghasilkan penjualan dan laba yang lebih tinggi.

Bila kepuasan pelanggan tidak dapat diandalkan, maka pengukuran apa yang terkait dengan pembelian ulang? Pengukuran tersebut adalah loyalitas pelanggan. Konsep loyalitas pelanggan lebih banyak dikaitkan dengan perilaku. Bila seseorang merupakan pelanggan loyal, ia menunjukkan perilaku perilaku pembelian yang didefinisikan sebagai pembelian nonrandom yang diungkapkan dari waktu ke waktu oleh beberapa unit pengambilan keputusan. Seorang pelanggan yang loyal memiliki prasangka spesifik mengenai apa yang akan dibeli dan dari siapa. Selain itu, loyalitas menunjukkan kondisi dari durasi waktu tertentu dan mensyaratkan bahwa tindakan pembelian terjadi tidak kurang dari dua kali. Sedangkan unit pengambilan keputusan menunjukkan bahwa keputusan untuk membeli mungkin dilakukan oleh lebih dari satu orang.

Loyalitas tentu tidak akan tercapai bila tidak dilengkapi dengan kualitas terhadap apa yang sedang dijalankan oleh perusahaan tersebut. Berkaitan dengan hal itu, kualitas yang dikemukakan dalam penelitian ini adalah kualitas jasa. 
Dimensi kualitas jasa yang dikemukakan oleh Parasuraman, Zeithaml dan Berry (1985) terdiri dari lima (5) yaitu tangibles, reliability, responsiveness, assurance dan empathy. Kelima dimensi itu dikenal dengan istilah SERVQUAL.

Dimensi-dimensi itu diperoleh melalui wawancara kelompok focus terhadap para pelanggan untuk mengetahui atribut apa saja yang diharapkan para pelanggan dari suatu perusahaan. Misalnya untuk mengukur harapan para pelanggan terhadap jasa perbankan tertentu, maka dilakukan wawancara terhadap sejumlah pelanggan yang merupakan nasabah bank tersebut. Jadi, harus diukur persepsi mereka terhadap jasa bank tersebut yang telah mereka terima selama ini. Persepsi itu diukur dengan menggunakan kelima dimensi untuk mengukur harapan para pelanggan.

Terdapat dua faktor yang sangat penting bila perusahaan ingin mengembangkan loyalitas yaitu keterikatan yang tinggi terhadap produk atau jasa tertentu dibanding terhadap produk atau jasa pesaing potensial dan pembelian yang berulang. Keterikatan yang dirasakan pelanggan terhadap produk atau jasa dibentuk oleh dua dimensi yaitu tingkat preferensi (seberapa besar keyakinan pelanggan terhadap produk atau jasa tertentu) dan tingkat diferensiasi produk yang dipersepsikan (seberapa signifikan pelanggan membedakan produk atau jasa tertentu dari alternatif-alternatif lain)

Setelah keterikatan yaitu pembelian berulang. Empat jenis loyalitas akan muncul bila faktor keterikatan dan pembelian berulang diklasifikasi silang. Jenisjenis loyalitas tersebut adalah : 
1. Tanpa Loyalitas

Pelanggan tidak mengembangkan loyalitas terhadap produk atau jasa tertentu. Misalnya menabung tidak ada bedanya tidak peduli di bank mana.

2. Loyalitas Lemah

Keterikatan yang rendah digabung dengan pembelian berulang yang tinggi. Pelanggan jenis ini membeli suatu produk atau jasa karena kebiasaan atau selalu menggunakannya. Loyalitas jenis ini paling umum terjadi pada produk yang sering dibeli. Pembeli ini rentan beralih ke produk pesaing yang dapat menunjukkan manfaat yang jelas.

3. Loyalitas Tersembunyi

Tingkat preferensi yang relatif tinggi digabungkan dengan tingkat pembelian berulang yang rendah. Dalam hal ini pengaruh situasi yang menentukan pembelian berulang. Misalnya, A menggemari masakan Cina dan mempunyai restoran Cina favorit, tetapi suaminya kurang menyukainya. Terlepas dari loyalitas, A hanya mendatangi restoran Cina sesekali saja dan memilih pergi ke restoran yang dapat dinikmati keduanya.

4. Loyalitas Premium

Jenis loyalitas yang paling dapat ditingkatkan dan terjadi jika ada tingkat keterikatan dan pembelian berulang yang tinggi. Loyalitas ini lebih disukai pelanggan di setiap perusahaan. Pelanggan akan merasa bangga karena menemukan dan menggunakan produk tertentu dan senang membagi pengetahuannya dengan rekan dan keluarga. Pelanggan ini akan selalu menjadi pendukung utama produk atau jasa tersebut dan selalu menyarankan orang lain untuk membelinya. 
Jadi, apabila dikaitkan dengan penelitian ini, maka jika kualitas pelayanan bank semakin baik akan menjadikan loyalitas nasabah juga semakin baik. Hal ini menunjukkan adanya hubungan yang relevan atau searah diantara kedua variabel tersebut. Disamping itu kualitas layanan bank berhubungan positif dengan kualitas nasabah. Artinya dengan pelayanan bank yang semakin berkualitas maka kualitas nasabah juga akan semakin baik dengan terbantunya usaha mereka. Dari gambaran di atas, secara keseluruhan dapat diambil kesimpulan bahwa kuantitas nasabah akan semakin banyak apabila pelayanan bank semakin baik.

\subsection{Rumusan Masalah}

Berdasarkan uraian singkat di atas, perumusan masalah yang dapat disimpulkan adalah bagaimana hubungan antara kualitas dan loyalitas nasabah PT. Bank Rakyat Indonesia (Persero) Tbk Kota Medan.

\subsection{Tujuan Penelitian}

Penelitian ini dilakukan untuk menguji hubungan antara kualitas dan loyalitas nasabah PT. Bank Rakyat Indonesia (Persero) Tbk Kota Medan dengan model Bloemer, Ruyter dan Wetzels (1998).

\subsection{Batasan Masalah}

Pada penelitian ini permasalahan yang akan diuji hanya terbatas pada pengujian dari variabel-variabel yang terdapat pada kualitas dan loyalitas jasa bank serta hubungan antara keduanya. 


\subsection{Manfaat Penelitian}

Hasil dari penelitian ini diharapkan dapat memberikan masukan-masukan yang positif bagi dunia perbankan khususnya PT. Bank Rakyat Indonesia (Persero) Tbk Kota Medan dalam menumbuhkan dan mempertahankan nasabahnya agar tetap menyimpan dananya pada bank ini serta diharapkan dapat dijadikan masukan bagi bidang pemasaran bank ini dalam mengembangkan program-program yang berhubungan dengan layanan terhadap nasabah. 


\section{BAB II}

\section{TINJAUAN KEPUSTAKAAN}

\subsection{Kualitas Jasa}

Kualitas jasa didefinisikan sebagai "fokus yang dilakukan perusahaan pada pemenuhan kebutuhan dan keinginan konsumen serta bagaimana cara yang sebaiknya dilakukan oleh perusahaan dalam menyampaikan jasa sesuai dengan harapan konsumen”. Kualitas jasa merupakan sikap dan penilaian konsumen secara global yang berkaitan dengan jasa dan hasil dari perbandingan persepsi dan harapan dengan jasa yang sebenarnya diterima konsumen (Berry et al., 1985, 1988; Cronroos, 1984). Pada umumnya harapan konsumen semakin meningkat dan mereka semakin kritis terhadap kualitas jasa yang mereka terima.

Batasan kualitas jasa terfokus pada interaksi antara jasa perusahaan dan pelanggannya dan berkaitan dengan hal-hal sebagai berikut :

- Dimensi teknikal seperti hasil dari sebuah proses jasa termasuk sistem dan teknologi

- Dimensi fungsional seperti cara bagaimana jasa disampaikan termasuk interaksi interpersonal

- Dimensi citra korporat yang merupakan hasil yang dirasa konsumen dari sebuah perusahaan

Pengukuran kualitas jasa secara garis besarnya berkisar tentang Service Quality Gap Model yang dikemukakan oleh Zeithaml et al (1988), dimana terdapat perbedaan antara harapan dan persepsi konsumen yang tergantung kepada empat (4) perbedaan lain yang berkaitan dengan penyampaian jasa. Dari Program Studi Magister Manajemen Program Pascasarjana Universitas Syah Kuala Nangroe Aceh Darussalam 
penelitian, mereka membentuk instrumen SERVQUAL untuk mengukur kualitas jasa (Parasuraman et al., 1988). SERVQUAL meliputi 22 item yang diperinci dalam lima (5) dimensi kualitas jasa.

Berdasarkan sebuah penelitian mengenai penilaian pelajar terhadap lembaga perbankan diperoleh hasil yang menyarankan beberapa faktor yang harus difokuskan untuk mendapatkan hubungan yang baik antara bank dengan pelajar seperti :

a. Bank harus mendefinisikan biaya tambahan dengan jelas

b. Pekerja harus memiliki waktu yang lebih untuk memberikan masukan

c. kepada pelanggan

d. Pinjaman harus diutamakan kepada pelanggan yang sangat membutuhkan

e. Para pekerja harus menghormati pelanggan

f. Para pekerja harus bersimpati dan memberikan keyakinan kepada pelanggan

Jadi, intinya hasil penelitian tersebut lebih memfokuskan kepada perilaku para pekerja bank untuk memenuhi kebutuhan khusus para pelajar (Lewis, Orledge dan Mitchell, 1994).

Nasabah baru harus dibuat tertarik untuk melakukan transaksi pada sebuah bank melalui program-program pemasarannya. Misalnya mempromosikan kemampuan bank untuk memberikan pelayanan yang superior dibanding pesaingnya. Untuk mencapai hal tersebut perlu dilakukan pelatihan kepada para pekerja bank. Menarik nasabah baru dari segmen yang tepat merupakan sebuah peluang bagi bank yang mempunyai cabang dan jaringan ATM yang luas. Namun, strategi utama yang harus dilakukan oleh institusi keuangan adalah konsumen 
harus disegmenkan menjadi dua dimensi utama berdasarkan ketepatan dan pelaksanaan kualitas jasa tersebut. Jadi, loyalitas konsumen akan sangat tergantung kepada manfaat-manfaat utama tersebut (McDougall dan Levesque, 1994).

\subsection{Dimensi Kualitas Jasa}

Pengembangan dimensi kualitas mencakup bukan hanya pelanggan tetapi juga eksekutif perusahaan penghasil produk atau jasa dan semua pihak yang terkait dengan distribusi pemasaran suatu produk. Seperti yang telah dinyatakan di atas, dimensi kualitas jasa terdiri dari lima (5) yaitu :

\section{Tangibles}

Dimensi ini mencakup kondisi fisik fasilitas, peralatan serta penampilan pekerja. Karena jasa tidak dapat diamati secara langsung, maka pelanggan selalu berpedoman pada kondisi yang terlihat mengenai jasa dalam melakukan evaluasi. Objeknya sangat bervariasi seperti karpet, tempat duduk, pencahayaan, warna dinding, korespondensi, brosur, penampilan pekerja, keramahan pekerja dan lainlain. Pernyataan-pernyataan berikut merupakan ukuran harapan maupun persepsi pelanggan.

\section{Harapan :}

a. Perusahaan-perusahaan yang unggul memiliki peralatan yang modern

b. Fasilitas fisik pada perusahaan-perusahaan yang unggul menarik untuk dilihat

c. Pekerja perusahaan-perusahaan yang unggul berpenampilan rapi

d. Materi yang berkaitan dengan pelayanan seperti pamflet pada 
e. perusahaan-perusahaan yang unggul menarik untuk dilihat

\section{Persepsi :}

a. Perusahaan ini memiliki peralatan yang modern

b. Fasilitas fisik perusahaan ini menarik untuk dilihat

c. Pekerja perusahaan ini berpenampilan menarik

d. Materi yang berkaitan dengan pelayanan perusahaan ini menarik untuk dilihat

\section{Reliability}

Dimensi ini menunjukkan kemampuan perusahaan untuk memberikan pelayanan secara akurat dan andal, dapat dipercaya, bertanggung jawab atas apa yang dijanjikan, tidak pernah memberikan janji yang berlebihan dan selalu memenuhi janji. Pernyataan-pernyataan berikut merupakan ukuran harapan maupun persepsi pelanggan.

\section{Harapan :}

a. Jika perusahaan-perusahaan yang unggul menjanjikan untuk melakukan sesuatu pada waktu tertentu, mereka akan melakukan hal itu

b. Jika pelanggannya bermasalah, perusahaan-perusahaan yang unggul akan menunjukkan perhatian yang tulus untuk menyelesaikannya

c. Perusahaan-perusahaan yang unggul melayani dengan benar pada waktu pertama kali (tidak dengan trial and error)

d. Perusahaan-perusahaan yang unggul akan melayani sesuai dengan waktu yang dijanjikan

e. Perusahaan-perusahaan yang unggul akan memiliki kebijakan agar hasilnya bebas dari kesalahan 
Persepsi :

a. Jika perusahaan ini menjanjikan untuk melakukan sesuatu pada waktu tertentu, maka hasilnya memang demikian

b. Jika pelanggan bermasalah, perusahaan ini menunjukkan perhatian yang tulus untuk menyelesaikannya

c. Perusahaan ini melayani dengan benar pada waktu pertama kali

d. Perusahaan ini melayani sesuai dengan waktu yang dijanjikan

e. Perusahaan ini menggunakan kebijakan agar hasilnya bebas dari kesalahan

\section{Responsiveness}

Dimensi ini mencakup keinginan untuk membantu pelanggan dan memberikan pelayanan yang cepat dan tepat, selalu memperoleh definisi yang tepat dan segera mengenai pelanggan. Dimensi ini merefleksikan komitmen perusahaan untuk memberikan pelayanannya tepat pada waktunya dan juga persiapan perusahaan sebelum memberikan pelayanan. Pernyataan-pernyataan berikut merupakan ukuran harapan maupun persepsi pelanggan.

\section{Harapan :}

a. Pekerja perusahaan-perusahaan yang unggul akan memberitahukan secara pasti kepada pelanggan kapan pelayanan akan dilakukan

b. Pekerja perusahaan-perusahaan yang unggul akan memberi pelayanan dengan cepat dan tepat kepada pelanggan

c. Pekerja perusahaan-perusahaan yang unggul akan selalu berkeinginan untuk membantu pelanggan

d. Pekerja perusahaan-perusahaan yang unggul tidak akan pernah terlalu sibuk untuk menanggapi tuntutan pelanggan 
Persepsi :

a. Pekerja perusahaan ini memberitahu pelanggan secara pasti kapan akan dilayani

b. Pekerja perusahaan ini memberikan pelayanan yang cepat dan tepat

c. Pekerja perusahaan ini selalu berkeinginan membantu pelanggan

d. Pekerja perusahaan ini tidak pernah terlalu sibuk untuk menanggapi tuntutan saya

\section{Assurance}

Dimensi ini terdiri dari empat (4) hal :

a. Competency. Mencakup kepemilikan keterampilan dan pengetahuan yang diperlukan

b. Courtesy. Mencakup kesopanan, rasa hormat, perhatian dan keramahan pelayan

c. Credibility. Mencakup kepercayaan terhadap dan kejujuran dari si pemberi jasa

d. Security. Mencakup kebebasan dari bahaya, resiko atau keragu-raguan

Dimensi ini mencakup pengetahuan dan kesopanan pekerja serta kemampuannya untuk memberikan kepercayaan kepada pelanggan. Dimensi ini merefleksikan kompetensi perusahaan, keramahan (kesopan-santunan) kepada pelanggan dan keamanan operasinya. Kompetensi berkaitan dengan pengetahuan dan keterampilan dalam memberikan jasa. Keramahan mengacu pada bagaimana pekerja perusahaan berinteraksi dengan pelanggannya dan kepemilikan pelanggan. Keamanan merefleksikan perasaan pelanggan bahwa ia 
bebas dari bahaya, resiko dan keragu-raguan. Pernyataan-pernyataan berikut merupakan ukuran harapan maupun persepsi pelanggan.

\section{Harapan :}

a. Perilaku pekerja perusahaan-perusahaan yang unggul akan menimbulkan kepercayaan pada pelanggannya

b. Pelanggan perusahaan-perusahaan yang unggul akan merasa aman atas transaksinya

c. Pekerja perusahaan-perusahaan yang unggul akan secara konsisten ramah kepada pelanggannya

d. Pekerja perusahaan-perusahaan yang unggul akan memiliki pengetahuan untuk menjawab pertanyaan pelanggannya

Persepsi :

a. Perilaku pekerja perusahaan ini menimbulkan kepercayaan kepada Pelanggan

b. Pelanggan merasa aman atas transaksi pelanggan dengan perusahaan ini

c. Pekerja perusahaan ini secara konsisten ramah terhadap pelanggan

d. Pekerja perusahaan ini memiliki pengetahuan untuk menjawab pertanyaan pelanggan

\section{Empathy}

Dimensi ini terdiri dari tiga (3) hal :

a. Accessibility. Mencakup kemudahan untuk mendekati dan menghubungi

b. Communication skills. Mencakup pemberian informasi kepada pelanggan dengan bahasa yang dapat dimengerti dan mendengarkan tanggapan dan pertanyaan pelanggan 
c. Understanding the customer. Mencakup perlunya usaha untuk mengetahui pelanggan dan kebutuhan khususnya

Dimensi ini menunjukkan derajat perhatian yang diberikan kepada setiap pelanggan. Dimensi ini juga merefleksikan kemampuan pekerja untuk menyelami perasaan pelanggan sebagaimana jika pekerja itu sendiri mengalaminya. Pernyataan-pernyataan berikut merupakan ukuran harapan maupun persepsi pelanggan.

Harapan :

a. Perusahaan-perusahaan yang unggul akan memberikan perhatian secara individual kepada pelanggannya

b. Perusahaan-perusahaan yang unggul memiliki jam operasi yang sesuai untuk semua pelanggannya

c. Perusahaan-perusahaan yang unggul memiliki pekerja yang memberikan perhatian khusus kepada pelanggannya

d. Perusahaan-perusahaan yang unggul akan memiliki perhatian terbaik secara tulus kepada pelanggannya

e. Pekerja perusahaan-perusahaan yang unggul memahami kebutuhan khusus pelanggannya

Persepsi :

a. Perusahaan ini memberikan pelanggan perhatian secara individual

b. Jam operasi perusahaan ini sesuai untuk pelanggan

c. Perusahaan ini memiliki pekerja yang memberikan perhatian secara pribadi kepada pelanggan

d. Perusahaan ini memberikan perhatian terbaik secara tulus kepada 
pelanggan

e. Pekerja perusahaan ini memahami kebutuhan khusus pelanggan

\subsection{Loyalitas Jasa}

Loyalitas Jasa dapat didefinisikan "sebagai suatu perilaku pembelian yang diungkapkan dari waktu ke waktu dan mensyaratkan bahwa tindakan pembelian terjadi tidak kurang dari dua kali”. Jadi pelanggan yang loyal adalah orang yang melakukan pembelian berulang secara teratur, membeli antarlini produk dan jasa, mereferensikan kepada orang lain dan menunjukkan kekebalan terhadap tarikan dari pesaing.

Penelitian terhadap loyalitas konsumen telah difokuskan terutama kepada loyalitas produk atau merek, sedangkan loyalitas terhadap jasa jarang dipublikasikan (Gremier dan Brown, 1996). Selalunya, hubungan yang sangat signifikan antara kepuasan dan loyalitas produklah yang dilaporkan. Mengacu kepada loyalitas konsumen, kualitas jasa merupakan kata kuncinya (Dick dan Basu, 1994). Ada beberapa alasan mengapa penelitian mengenai loyalitas produk tidak dapat digeneralisasikan dengan loyalitas jasa (Keaveney, 1995; Gremler dan Brown, 1996). Loyalitas jasa lebih mengarah kepada pembentukan hubungan interpersonal yang berbeda dari loyalitas produk (Macintosh dan Lockshin, 1998), bentuk interaksi antar individu yang merupakan elemen penting dalam pemasaran jasa (Czepiel dan Gilmore, 1987; Surprenant dan Solomon, 1987; Crosby et al., 1990; Czepiel, 1990). Selanjutnya, resiko yang dirasa konsumen lebih besar pada kasus jasa sebagaimana loyalitas konsumen yang menjadi penghalang terhadap perilaku berpindah konsumen (Zeithaml, 1981; Klemperer, 1987; Guiltinan, 
1989). Loyalitas lebih lazim didemonstrasikan oleh perusahaan jasa dibanding perusahaan penghasil produk (Snyder, 1986). Pada konteks jasa, atribut yang tidak berwujud seperti faktor yang dapat dipercaya dan keyakinan berperan penting dalam membentuk loyalitas (Dick dan Basu, 1994).

Sebagaimana mayoritas penelitian di bidang manufaktur (Jacoby dan Chestnut, 1978), penekanan utamanya adalah ukuran perilaku. Pada konteks jasa, loyalitas selalu didefinisikan sebagai observasi terhadap perilaku (Liljander dan Strandvik, 1995). Lebih lanjut, perilaku pembelian berulang merupakan penghalang bagi konsumen untuk berpindah ke jasa lain (Storbacka et al., 1994; Liljander dan Strandvik, 1995). Berkaitan dengan perilaku, terdapat argumen yang menyatakan bahwa terdapat sisi kognitif dari loyalitas konsumen (Lee dan Zeiss, 1980) dimana loyalitas konsumen selalu dioperasionalkan sebagai produk atau jasa yang pertama sekali muncul di dalam fikiran ketika membuat keputusan pembelian (Newman dan Werbel, 1973; Bellenger et al., 1976; Dwyer et al., 1987) produk atau jasa yang dipilih pertama sekali oleh konsumen diantara pilihan lain (Ostrowski e al., 1993) atau harga yang dipertimbangkan (Anderson, 1996; Fornell et al., 1996).

Secara umum, loyalitas pelanggan terjadi disebabkan karena adanya pemenuhan kebutuhan dan keinginan mereka oleh perusahaan tertentu terhadap suatu produk dan akibatnya, pelanggan tidak akan mencari perusahaan lain sejenis untuk mendapatkan apa yang mereka ingin dan butuhkan. Jadi, dalam penelitian ini BRI berupaya untuk menjadikan dirinya semakin intens berinteraksi dua arah dengan nasabahnya dan berupaya untuk saling tukar informasi antar BRI dengan 
nasabahnya sehingga BRI tidak hanya sampai pada Costumer Oriented tetapi lebih jauh lagi menjadikan nasabah loyal kepada BRI.

Sebuah penelitian empiris yang sederhana telah difokuskan kepada hubungan antara loyalitas konsumen dan persepsi kualitas jasa. Berdasarkan perilaku dalam konteks jasa, Zeithaml et al. (1996) mengemukakan sebuah kerangka kerja yang komprehensif dan multi dimensi.

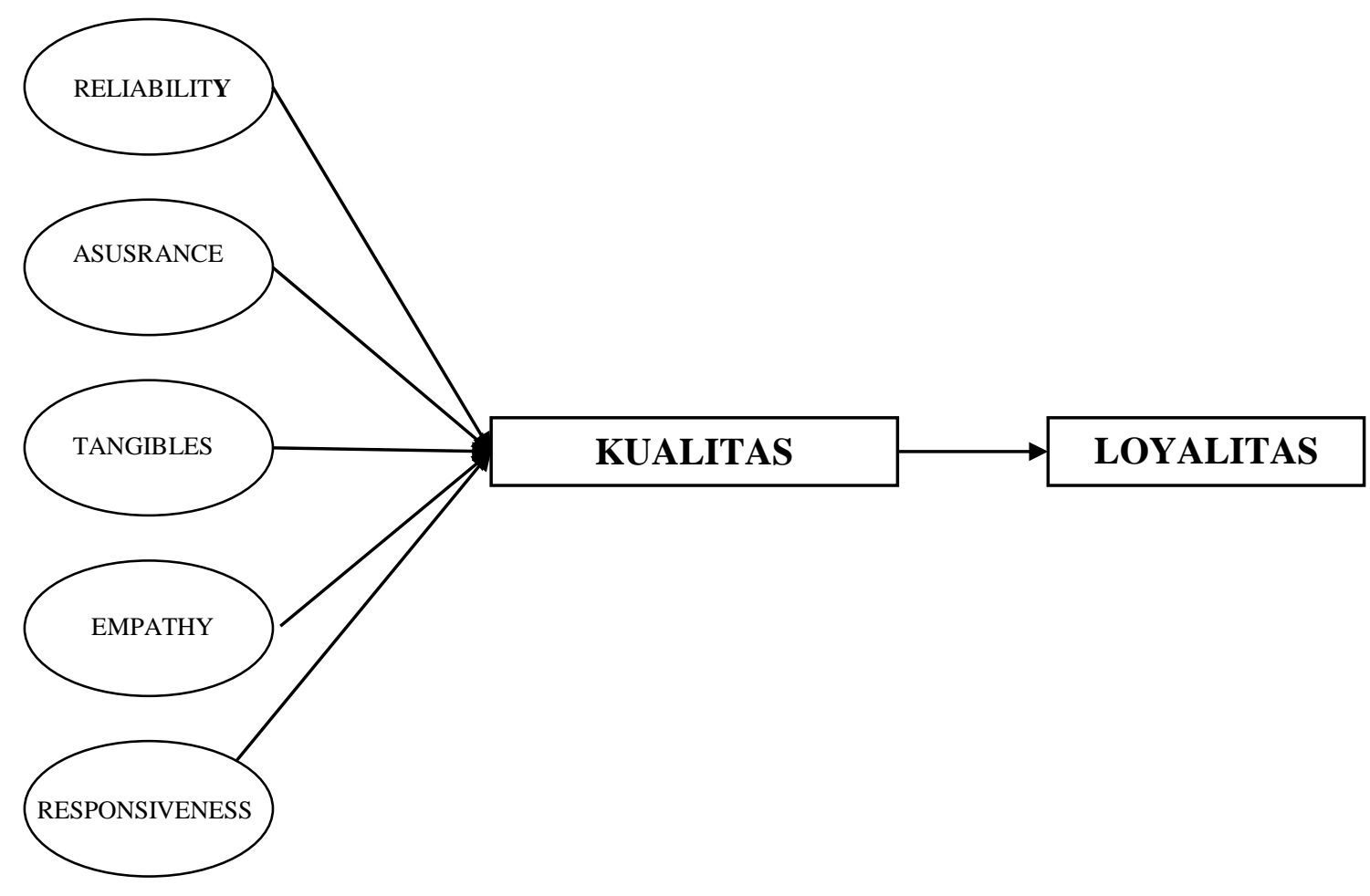

Gambar 1. Model Hubungan Kualitas dan Loyalitas Jasa

\subsection{Hipotesis}

Penelitian ini menguji hipotesis sebagai berikut :

Terdapat hubungan yang signifikan antara kualitas dan loyalitas jasa perbankan PT. Bank Rakyat Indonesia (Persero) Tbk Kota Medan. 


\section{BAB III}

\section{METODOLOGI PENELITIAN}

\subsection{Lokasi dan Objek Penelitian}

Penelitian ini dilakukan pada PT. Bank Rakyat Indonesia (Persero), Tbk Kota Medan untuk melihat hubungan antara kualitas dan loyalitas jasa perbankan pada instansi ini.

\subsection{Metode Pengambilan Sampel}

Penelitian ini dilakukan kepada nasabah PT. Bank Rakyat Indonesia (Persero), Tbk Kota Medan dengan jumlah sample sebanyak 210 orang sebagai responden. Metode pengambilan sampel yang digunakan adalah sampel kluster, dimana kelompok yang mempunyai sifat heterogen diidentifikasi terlebih dahulu lalu dipilih secara random. Akhirnya semua elemen dari hasil random tersebut diteliti.

\subsection{Populasi dan Pemilihan Responden}

Pendefenisian populasi dalam penelitian ini adalah para nasabah yang ada pada kantor cabang BRI yang ada di Medan. Untuk setiap kantor cabang dikuotakan 70 responden sehingga jumlah nasabah yang menjadi sasaran penelitian sebanyak 210 responden dari tiga cabang BRI yang ada di kota Medan Yaitu BRI Cabang Medan Putri Hijau, Medan Iskandar Muda dan Medan Sisingamangaraja. Mengikuti Ma'ruf (2005) yang merujuk kepada Sudman 
(1983), menyarankan bahwa riset atau penelitian tentang sikap usianya minimum yang menjadi responden adalah 18 tahun.

Mengingat riset atau penelitian ini banyak menggunakan pengukuranpengukuran psikologis, maka ditetapkan bahwa yang menjadi responden dibatasi pada usia minimum 18 tahun.

\subsection{Teknik pengukuran}

Pada penelitian atau riset ini konsep pengukuran merujuk pada Bansal dan Taylor (1999), dimana seluruh konstruk kualitas layanan (service quality) diukur dengan menggunakan five item scale yang merujuk pada Taylor dan Baker (1994).

\subsubsection{Kualitas Jasa}

Defenisi kualitas layanan (service quality) berdasarkan Bitner dan Hubert (1994, p.77), adalah "kesan yang diterima oleh pelanggan akibat dari superioritas suatu layanan sebuah organisasi atau perusahaan" (dikutip dari Bansal dan Taylor, 1999). Untuk konstruk tersebut ketiga indikator yang digunakan diukur dengan skala likert 5 titik pada setiap indikatornya : (1) Secara keseluruhan Bank telah memberikan pelayanan yang terbaik, $1=$ Sangat tidak setuju $\rightarrow 5=$ Sangat setuju; (2) Menurut saya secara umum pelayanan bank buruk, $1=$ Sangat tidak setuju $\rightarrow$ 5 = Sangat setuju; (3) Kualitas Pelayanan Bank ini menurut saya biasa saja, $1=$ Sangat tidak setuju $\rightarrow 5$ = Sangat setuju

\subsubsection{Loyalitas Jasa}

Kesetiaan dinyatakan sebagai petunjuk tahap konsumen yang paling tinggi (James et al. 1975). Kesetiaan adalah kecenderungan untuk seseorang 
menunjukkan perbuatan yang sama berulangkali pada keadaan yang sama yang telah dihadapi sebelumnya.

Terdapat beberapa dimensi dalam kesetiaan konsumen :

- Pengulangan

Terdapat dua perspektif di dalam pengulangan yakni frekuensi menabung dan mendatangi bank tertentu dibanding dengan bank lain pada masa tertentu. Menabung dan mendatangi bank oleh nasabah pada bank tertentu ditentukan sebagai suatu proses penilaian (spiggle dan Sewall, 1987) atau sebagai suatu proses penelitian (Tucker, 1964). Penilaian positif yang kuat yang dibentuk melalui proses ini akan mengukuhkan perilaku konsumen untuk mengulangi kedatangannya ke bank tertentu.

- Prioritas

Spiggle dan Sewall (1987) mengatakan bahwa konsumen yang setia mempunyai prioritas yang kuat terhadap bank yang mereka sukai. Oleh itu, dimensi ini dapat diartikan sebagai kecenderungan untuk

Penelitian empiris telah dilakukan oleh Zeithaml et al (1996) yang memfokuskan tentang hubungan antara kualitas jasa dengan loyalitas konsumen yang didasarkan kepada perilaku. Beliau menyarankan kerangka kerja multi dimensi mengenai perilaku dalam sektor jasa.

Indikator-indikator yang mempengaruhi loyalitas sebagai berikut :

1. Mengatakan sesuatu yang positif mengenai BRI kepada orang lain

2. Merekomendasikan BRI kepada orang lain

3. Menyarankan teman dan saudara melakukan transaksi dengan BRI 
4. Mempertimbangkan BRI sebagai pilihan pertama untuk menggunakan jasanya

5. Melakukan transaksi lebih banyak dengan BRI untuk tahun-tahun berikutnya

6. Melakukan transaksi lebih sedikit dengan BRI untuk tahun-tahun berikutnya

7. Bekerja sama dengan pesaing yang menawarkan pelayanan yang lebih menarik

8. Melanjutkan kerja sama dengan pesaing yang menawarkan pelayanan yang lebih menarik

9. Memberikan pelayanan yang lebih baik dibanding pesaing untuk meningkatkan manfaat bagi BRI

10. Berpindah ke pesaing apabila bermasalah dengan pelayanan BRI

11. Menyatakan keluhan kepada nasabah yang lain apabila bermasalah dengan pelayanan BRI

12. Menyatakan keluhan kepada pihak luar selain nasabah bila bermasalah dengan pelayanan BRI

13. Menyatakan keluhan kepada karyawan BRI bila bermasalah dengan pelayanan BRI

\subsection{Model Analisis}

Untuk mengetahui apakah terdapat hubungan yang signifikan antara kualitas dan loyalitas jasa pada bank yang diteliti, maka akan dilakukan pengujian 
hubungan berbagai variable kualitas dengan loyalitas dengan menggunakan analisis korelasi.

\subsection{Teknik Pengumpulan Data}

Untuk mendapatkan data dan informasi yang diperlukan dalam penelitian ini dilakukan pengumpulan data melalui sbb :

a. Data Primer.

Yang merupakan sumber dari data lapangan melalui observasi lapangan, wawancara serta menyebarkan kuesioner kepada responden dari masing-masing kantor cabang PT. Bank Rakyat Indonesia (Persero) Tbk Kota Medan yakni Kantor Cabang Medan Putri Hijau, Iskandar Muda dan Sisingamangaraja.

b. Data Sekunder.

Yaitu data yang diperoleh dari laporan pemasaran dan keuangan PT. Bank Rakyat Indonesia (Persero) Tbk, buku - buku, karya ilmiah, buletin BRI dan literatur.

\subsection{Skala Pengukuran}

Untuk mengukur variabel-variabel dalam penelitian ini digunakan skala Likert dengan lima rentangan. Skala Likert digunakan untuk mengukur item-item pernyataan yang bersifat positif terhadap masalah yang diteliti maupun pernyataan.

Pengukuran pernyataan bersifat positif dengan Skala Likert sebagai berikut: 
Thesis : Dedy Ansari Harahap (21 Juli 2006)

Hubungan Kualitas dan Loyalitas Nasabah Jasa Perbankan

PT. Bank Rakyat Indonesia (Persero) Tbk Kota Medan

\begin{tabular}{cccccc}
\hline $\begin{array}{c}\text { Alternatif } \\
\text { Jawaban }\end{array}$ & $\begin{array}{c}\text { Sangat } \\
\text { Setuju }\end{array}$ & Setuju & $\begin{array}{c}\text { Kurang } \\
\text { Setuju }\end{array}$ & $\begin{array}{c}\text { Tidak } \\
\text { Setuju }\end{array}$ & $\begin{array}{c}\text { Sangat tidak } \\
\text { Setuju }\end{array}$ \\
\hline Nilai & 5 & 4 & 3 & 2 & 1 \\
\hline
\end{tabular}

Nilai 5 akan diberikan pada responden yang memberikan tanggapan sangat setuju terhadap pernyataan. Nilai 4 akan diberikan jika responden memberikan tanggapan setuju terhadap pernyataan. Nilai 3 akan diberikan jika responden kurang setuju terhadap pernyataan. Nilai 2 akan diberikan pada responden yang tidak setuju. Nilai 1 akan diberikan jika responden memberikan tanggapan sangat tidak setuju terhadap pernyataan.

Kemudian setelah dilakukan pembobotan jawaban, berdasarkan skala likert (rentang antara 1-5) untuk selanjutnya data-data berbentuk angka tersebut diolah melalui program Statistical Program for Social Science (SPSS) dengan model/metode uji t.

\subsection{Uji Reliabilitas Variabel Penelitian}

Keandalan atau reliabilitas diartikan sebagai seberapa jauh pengukuran bebas dari varian kesalahan acak. Kesalahan acak akan menurunkan tingkat keandalan hasil pengukuran. Kalau menghendaki agar merasa yakin bahwa nilai atau skor dari kuesioner dapat mencerminkan dimensi kepuasan secara andal, penelitian yang dilakukan harus menunjukkan keandalan yang tinggi. Koefisien Cronbach Alpha adalah suatu alat analisis penilaian keandalan (reliabilitas tes dari suatu skala yang dibuat). Cara ini untuk menghitung korelasi skala yang dibuat dengan seluruh variabel yang ada, dengan angka keofisien yang dapat diterima adalah di atas 0,5 menurut Nunally (1967) dan diatas 0,6 menurut Malhotra (1996). 


\subsection{Uji Hipotesis}

Terdapat hubungan yang signifikan antara kualitas dan loyalitas jasa perbankan PT. Bank Rakyat Indonesia (Persero) Tbk Kota Medan. Apabila t. hit >

t. tabel pada $\alpha=0,05$ maka terbukti ada hubungan antara kualitas dan loyalitas jasa perbankan PT. Bank Rakyat Indonesia (Persero), Tbk. 


\section{BAB IV}

\section{HASIL PENELITIAN DAN PEMBAHASAN}

\section{Karakteristik Responden}

Dari hasil data kuesioner terhadap 210 orang responden telah diperoleh data-data sebagai berikut :

Tabel 1

Karakteristik Responden

\begin{tabular}{|c|c|c|c|c|}
\hline \multicolumn{2}{|c|}{ URAIAN } & \multirow{2}{*}{$\begin{array}{r}\text { Frequency } \\
100\end{array}$} & \multirow{2}{*}{$\begin{array}{r}\text { Percent } \\
47.6\end{array}$} & \multirow{2}{*}{$\begin{array}{r}\begin{array}{c}\text { Cumulative } \\
\text { Percent }\end{array} \\
47.6\end{array}$} \\
\hline GENDER & LAKI-LAKI & & & \\
\hline & PEREMPUAN & 110 & 52.4 & 100.0 \\
\hline & Total & 210 & 100.0 & \\
\hline \multirow[t]{4}{*}{ STATUS } & KAWIN & 116 & 55.2 & 55.2 \\
\hline & BELUM KAWIN & 91 & 43.3 & 98.6 \\
\hline & DUDA/JANDA & 3 & 1.4 & 100.0 \\
\hline & Total & 210 & 100.0 & \\
\hline \multirow[t]{6}{*}{ USIA } & $<20$ Tahun & 12 & 5.7 & 5.7 \\
\hline & 20 - 30 Tahun & 98 & 46.7 & 52.4 \\
\hline & 31 - 40 Tahun & 33 & 15.7 & 68.1 \\
\hline & 41 - 50 Tahun & 53 & 25.2 & 93.3 \\
\hline & $>50$ Tahun & 14 & 6.7 & 100.0 \\
\hline & Total & 210 & 100.0 & \\
\hline \multirow[t]{7}{*}{ PENDIDIKAN } & SD & 3 & 1.4 & 1.4 \\
\hline & SMA & 58 & 27.6 & 29.0 \\
\hline & AKADEMI/D3 & 55 & 26.2 & 55.2 \\
\hline & SARJANA & 87 & 41.4 & 96.7 \\
\hline & PASCA SARJANA & 3 & 1.4 & 98.1 \\
\hline & LAIN-LAIN & 4 & 1.9 & 100.0 \\
\hline & Total & 210 & 100.0 & \\
\hline
\end{tabular}

Sumber : Data Primer, 2006 (diolah) 
Tabel 2

Karakteristik Responden Lanjutan

\begin{tabular}{llrrr}
\hline & URAIAN & Frequency & Percent & $\begin{array}{c}\text { Cumulative } \\
\text { Percent }\end{array}$ \\
\hline PEKERJAAN & PNS & 64 & 30.5 & 30.5 \\
& TNI/POLRI & 6 & 2.9 & 33.3 \\
& PEGAWAI & 3 & 1.4 & 34.8 \\
& BUMN/BUMD & & & \\
& KARYAWAN/WATI & 35 & 16.7 & 51.4 \\
& WIRASWASTA & 44 & 21.0 & 72.4 \\
& LAIN-LAIN & 58 & 27.6 & 100.0 \\
\hline PENDAPATAN & Total & 210 & 100.0 & \\
& 5 500.000,- & 30 & 14.3 & 14.3 \\
& 1.500.000,- & 101 & 48.1 & 62.4 \\
& $1.501 .000,-$ S/D & & & \\
& $2.500 .000,-$ & 66 & 31.4 & 93.8 \\
& $2.501 .000,-$ S/D & & & \\
& $3.500 .000,-$ & 5 & 2.4 & 96.2 \\
& $3.501 .000,-$ S/D & & & \\
& $4.500 .000,-$ & 6 & 2.9 & 99.0 \\
& $>4.500 .000,-$ & & & \\
\hline WARGA & Total & 2 & 1.0 & 100.0 \\
\hline WNGARA & WNI & 210 & 100.0 & \\
\hline & Total & 203 & 96.7 & 96.7 \\
\hline
\end{tabular}

Sumber : Data Primer, 2006 (diolah)

Dari tabel 1 atas menunjukkan karakteristik sosial demografi yaitu jenis kelamin laki-laki sebanyak 100 orang $(47,6 \%)$ dan perempuan sebanyak 110 orang $(52,4 \%)$. Berdasarkan status perkawinan sebanyak $116(55,2 \%)$ responden dinyatakan kawin (berkeluarga), tidak kawin sebanyak 91 orang $(43,3 \%)$ dan duda/janda sebanyak 3 orang (1,4\%). Usia responden dibawah 20 tahun sebanyak 12 orang $(5,7 \%), 20$ - 30 tahun sebanyak 98 orang (46,7\%), 31 - 40 tahun sebanyak 33 orang (15,7\%), 41 - 50 tahun sebanyak 53 orang $(25,2 \%)$ dan diatas 50 tahun sebanyak 14 orang $(6,7 \%)$. 
PT. Bank Rakyat Indonesia (Persero) Tbk Kota Medan

Responden yang berpendidikan terakhir yakni tamatan SD sebanyak 3 orang $(1,4 \%)$, SMA 58 orang $(27,6 \%)$, AKADEMI/D3 sebanyak 55 orang (26,2 $\%)$, SARJANA sebanyak 87 orang (41,4 \%), PASCASARJANA sebanyak 3 orang $(1,4 \%)$ dan LAIN-LAIN (dikategorikan tidak atau tidak tamat sekolah) sebanyak 4 orang $(1,9 \%)$.

Sedangkan pada table 2 responden yang mempunyai pekerjaan sebagai PNS sebanyak 64 orang (30,5\%), TNI/POLRI sebanyak 6 orang (2,9\%), PEGAWAI BUMN/BUMD sebanyak 3 orang $(1,4 \%)$, KARYAWAN/WATI sebanyak 35 orang $(16,7 \%)$, WIRASWASTA sebanyak 44 orang $(21,0 \%)$ dan LAIN-LAIN (dikategorikan mahasiswa/i, ibu rumah tangga atau pensiunan) sebanyak 58 orang $(27,6 \%)$. Dari segi pendapatan dari hasil kuesioner responden diperoleh yakni pendapatan dibawah Rp. 500.000,- sebanyak 30 orang (14,3\%), Rp. 501.000,- s/d Rp. 1.500.000,- sebanyak 101 orang (48,1 \%), Rp. 1.501.000,s/d Rp. 2.500.000,- sebanyak 66 orang (31,4 \%), Rp. 2.501.000,- s/d Rp. 3.500.000,- sebanyak 5 orang $(2,4 \%)$, Rp. 3.501.000,- s/d Rp. 4.500.000,sebanyak 6 orang $(2,9 \%)$ dan diatas Rp. 4.500.000,- sebanyak 2 orang $(1,0 \%)$.

Sedangkan untuk status kewarganegaraan responden dari hasil kuesioner diperoleh yakni ; untuk kewarganegaraan WNI sebanyak 203 orang (96,7 \%) dan selebihnya WNI keturunan sebanyak 7 orang $(3,3 \%)$ dari total 210 responden. Untuk data selengkapnya dapat dilihat pada tabel di bawah ini :

Instrumen penelitian terdiri dari 2 (dua) variabel yakni kualitas sebagai variabel bebas dan loyalitas sebagai variabel terikat. 
Tabel 3

Diskripsi Statistik Kualitas dan Loyalitas

Descriptive Statistics

\begin{tabular}{|l|r|r|r|r|r|r|}
\hline & \multicolumn{1}{|c|}{$\mathrm{N}$} & \multicolumn{1}{c|}{ Minimum } & \multicolumn{1}{c|}{ Maximum } & \multicolumn{2}{|c|}{ Mean } & \multicolumn{1}{c|}{ Std. } \\
\cline { 2 - 7 } & \multicolumn{1}{|c|}{ Statistic } & Stat istic & Statistic & \multicolumn{1}{c|}{ Statistic } & Std. Error & \multicolumn{1}{c|}{ Statistic } \\
\hline KUALITAS & 210 & 2.60 & 4.96 & 3.8503 & .02666 & .38641 \\
LOYALITAS & 210 & 2.50 & 4.70 & 3.5248 & .02225 & .32245 \\
Valid N (listwise) & 210 & & & & & \\
\hline
\end{tabular}

Sumber: Data Primer, 2006 (diolah)

Berdasarkan Tabel 1,2 dan 3 di atas dijelaskan bahwa pada dimensi kualitas mempunyai nilai rata-rata jawaban responden sebesar 3,8503, sedangkan untuk dimensi loyalitas nilai rata-rata jawaban responden 3,5248. Ini menunjukkan bahwa kualitas dan loyalitas berpengaruh signifikan terhadap jawaban responden.

Terbentuknya suatu persepsi, image, anggapan dari pelanggan yang berbeda-beda terhadap kualitas dan loyalitas dari para nasabah merupakan suatu hal yang sangat lumrah dan wajar adanya, karena pada dasarnya banyak jasa perbankan yang menawarkan jasa produknya dengan berbagai jenis/tipe, kelebihannya yang diberikan serta manfaat bagi nasabah sebagai konsumen. Kajian pada penelitian ini adalah untuk melihat Kualitas (K) dan Loyalitas (L) yang akan mempengaruhi nasabah dalam berhubungan dengan dunia perbankan dalam melakukan transaksi bisnisnya melalui suatu bank, dimana kualitas suatu jasa perbankan berpengaruh kepada loyalitas nasabah agar tetap berhubungan dengan satu bank saja, terutama pada studi kasus di PT. Bank Rakyat Indonsia (Persero), Tbk di kota Medan.

Sementara untuk instrumen penelitian terhadap distribusi frekuensi dari kualitas sebagai variabel bebas yang terdiri dari 25 indikator dapat dilihat sebagai berikut. 
Tabel 4

Frekuensi dan Persentase Variabel Kualitas

\begin{tabular}{|c|c|c|c|c|c|c|c|}
\hline \multirow{2}{*}{ No. } & \multirow{2}{*}{ Uraian } & \multicolumn{5}{|c|}{ Persentase Responden } & \multirow{2}{*}{$\begin{array}{l}\text { Rata- } \\
\text { Rata }\end{array}$} \\
\hline & & SS & $\mathbf{S}$ & KS & TS & STS & \\
\hline 1 & Perusahaan memiliki perlengkapan modern & 22,90 & 63,30 & 10,00 & 3,30 & 0,50 & 4,05 \\
\hline 2 & Fasilitas yang tersedia cukup menarik & 11,40 & 67,10 & 17,60 & 3,30 & 0,50 & 3,86 \\
\hline 3 & Karyawan cenderung berpenampilan rapi & 27,60 & 66,70 & 5,20 & 0,50 & - & 4,21 \\
\hline 4 & $\begin{array}{l}\text { Material yang berhubungan dengan pelayanan } \\
\text { (seperti pamphlet atau brosur) menarik bagi saya }\end{array}$ & 8,60 & 61,90 & 26,20 & 3,30 & - & 3,76 \\
\hline 5 & $\begin{array}{l}\text { Ketika perusahaan berjanji untuk melakukan } \\
\text { sesuatu pada waktu tertentu, senantiasa } \\
\text { menepatinya }\end{array}$ & 12,90 & 66,20 & 16,20 & 4,30 & 0,50 & 3,87 \\
\hline 6 & $\begin{array}{l}\text { Perusahaan memberikan solusi apabila saya } \\
\text { menghadapi masalah }\end{array}$ & 10,00 & 76,70 & 7,60 & 5,70 & - & 3,91 \\
\hline 7 & Perusahaan mengutamakan pelayanan & 24,30 & 58,60 & 12,90 & 4,30 & - & 4,03 \\
\hline 8 & Perusahaan mengutamakan pelayanan & 14,30 & 73,30 & 11,40 & 1,00 & - & 4,01 \\
\hline 9 & $\begin{array}{l}\text { Perusahaan tanggap dalam menyelesaikan } \\
\text { permasalahan operasional transaksi perbankan }\end{array}$ & 10,00 & 74,80 & 12,40 & 2,90 & - & 3,92 \\
\hline 10 & $\begin{array}{l}\text { Karyawan senantiasa menjelaskan dengan baik } \\
\text { atas pertanyaan yang diajukan }\end{array}$ & 19,00 & 61,00 & 17,60 & 2,40 & - & 3,97 \\
\hline 11 & $\begin{array}{l}\text { Karyawan memberikan pelayanan yang cepat } \\
\text { kepada saya }\end{array}$ & 12,40 & 54,80 & 27,60 & 4,30 & 1,00 & 3,73 \\
\hline 12 & Karyawan selalu berupaya untuk membantu saya & 7,10 & 73,30 & 17,60 & 1,90 & - & 3,86 \\
\hline 13 & $\begin{array}{l}\text { keberatan untuk memenuhi atas } \\
\text { an nasabah }\end{array}$ & 6,70 & 51,40 & 36,70 & 5,20 & - & 3,60 \\
\hline 14 & Karyawan cenderung menghubungi nasabah & 16,70 & 63,80 & 16,20 & 2,40 & 1,00 & 3,93 \\
\hline 15 & $\begin{array}{l}\text { Nasabah merasa aman pada saat melakukan } \\
\text { transaksi }\end{array}$ & 26,70 & 65,70 & 7,60 & 0,50 & - & 4,18 \\
\hline 16 & Karyawan selalu ingin tahu mengenai nasabahny & 2,90 & 41,90 & 48,10 & 5,70 & 1,40 & 3,39 \\
\hline 17 & $\begin{array}{l}\text { Karyawan mempunyai pengetahuan yang } \\
\text { mendalam untuk menjawab pertanyaan nasabah }\end{array}$ & 7,60 & 74,30 & 16,70 & 1,40 & - & 3,88 \\
\hline 18 & $\begin{array}{l}\text { Perusahaan memberikan perhatian penuh pada } \\
\text { masing-masing nasabah }\end{array}$ & 10,00 & 57,10 & 28,10 & 4,80 & - & 3,72 \\
\hline 19 & $\begin{array}{l}\text { Perusahaan selalu menanamkan keyakinan pada } \\
\text { nasabah }\end{array}$ & 13,80 & 71,90 & 11,40 & 2,90 & - & 3,97 \\
\hline 20 & $\begin{array}{l}\text { Perusahaan mempunyai karyawan yang memberi } \\
\text { perhatian pada masing-masing nasabah }\end{array}$ & 5,20 & 52,40 & 39,50 & 2,90 & - & 3,60 \\
\hline 21 & Perusahaan berusaha menarik hati nasabah & 16,70 & 60,50 & 19,50 & 2,40 & 1,00 & 3,90 \\
\hline 22 & $\begin{array}{l}\text { Karyawan memahami kebutuhan spesifik } \\
\text { nasabahnya }\end{array}$ & 3,80 & 51,90 & 41,40 & 2,90 & - & 3,57 \\
\hline 23 & $\begin{array}{l}\text { Bekerjasama dengan pesaing yang menawarkan } \\
\text { pelayanan yang lebih menarik }\end{array}$ & 6,70 & 57,60 & 30,50 & 5,20 & - & 3,66 \\
\hline 24 & $\begin{array}{l}\text { Melanjutkan kerjasama dengan pesaing yang } \\
\text { menawarkan pelayanan yang lebih menarik }\end{array}$ & 11,90 & 55,70 & 26,70 & 5,20 & 0,50 & 3,73 \\
\hline 25 & $\begin{array}{l}\text { Memberikan pelayanan yang lebih baik dibanding } \\
\text { pesaing untuk menambah manfaat bagi BRI }\end{array}$ & 19,00 & 62,40 & 15,20 & 3,30 & - & 3,97 \\
\hline
\end{tabular}

\section{Total Rata - Rata}

Sumber Data Penelitian

Keterangan : SS (Sangat Setuju), S (Setuju), KS (Kurang Setuju), TS'(Tidak Setuju) dan STS (Sangat Tidak Setuju)

Program Studi Magister Manajemen Program Pascasarjana

Universitas Syah Kuala Nangroe Aceh Darussalam 
Dilihat dari tabel 4 diatas persepsi responden terhadap kualitas dalam kaitannya terhadap jasa perbankan PT. Bank Rakyat Indonesia (Persero), Tbk Kota Medan dengan skor rata-rata tertinggi adalah item karyawan berpenampilan rapi (K3) sedangkan untuk skor rata-rata terendah adalah item karyawan selalu ingin tahu nasabahnya (K16), jika dilihat pada hasil jawaban responden menunjukkan dengan karyawan berpenampilan rapi (K3) menjadi salah satu indikator dalam menentukan kualitas jasa perbankan oleh nasabah yang dilakukan oleh responden.

Sementara untuk instrumen penelitian terhadap distribusi frekuensi dari loyalitas sebagai variabel terikat yang terdiri dari 10 indikator dapat dilihat sebagai berikut.

Tabel 5

Frekuensi dan Persentase Variabel Loyalitas

\begin{tabular}{|c|c|c|c|c|c|c|c|}
\hline \multirow{2}{*}{ No } & \multirow{2}{*}{ Uraian } & \multicolumn{5}{|c|}{ Persentase Responden } & \multirow{2}{*}{$\begin{array}{l}\text { Rata- } \\
\text { Rata }\end{array}$} \\
\hline & & SS & $\mathbf{S}$ & KS & TS & STS & \\
\hline 1 & $\begin{array}{l}\text { Saya senantiasa mengatakan sesuatu yang } \\
\text { positif mengenai BRI kepada orang lain }\end{array}$ & 7,10 & 71,40 & 20,00 & 1,40 & - & 3,84 \\
\hline 2 & $\begin{array}{l}\text { Saya selalumerekomendasikan BRI kepada } \\
\text { orang lain }\end{array}$ & 2,90 & 51,00 & 41,90 & 4,30 & - & 3,52 \\
\hline 3 & $\begin{array}{l}\text { Saya cenderung menyarankan teman dan } \\
\text { saudara melakukan transaksi dengan BRI }\end{array}$ & 6,70 & 53,80 & 31,90 & 7,60 & - & 3,60 \\
\hline 4 & $\begin{array}{l}\text { Saya akan mempertimbangkan BRI sebagai } \\
\text { pilihan pertama untuk menggunakan jasanya }\end{array}$ & 8,60 & 53,80 & 31,90 & 5,70 & - & 3,65 \\
\hline 5 & $\begin{array}{l}\text { Saya akan melakukan transaksi lebih bsnysk } \\
\text { dengan BRI untuk tahun-tahun berikutnya }\end{array}$ & 9,00 & 51,90 & 33,30 & 5,70 & - & 3,64 \\
\hline 6 & $\begin{array}{l}\text { Saya akan melakukan transaksi lebih sedikit } \\
\text { dengan BRI untuk tahun-tahun berikutnya }\end{array}$ & 0,50 & 18,60 & 58,10 & 21,00 & 1,90 & 2,95 \\
\hline 7 & $\begin{array}{l}\text { Saya tidak akan berpindah ke bank lain } \\
\text { meskipun pelayanan BRI kurang baik }\end{array}$ & 4,80 & 21,40 & 48,10 & 20,00 & 5,70 & 3,00 \\
\hline 8 & $\begin{array}{l}\text { Menyatakan keluhan kepada nasabah yang } \\
\text { lain apabila bermasalah dengan pelayanan } \\
\text { BRI }\end{array}$ & 2,90 & 56,70 & 27,60 & 10,50 & 2,40 & 3,47 \\
\hline 9 & $\begin{array}{l}\text { Menyatakan keluhan kepada pihak luar } \\
\text { selain nasabah bila bermasalah dengan } \\
\text { pelayanan BRI }\end{array}$ & 3,30 & 43,30 & 35,70 & 15,70 & 1,90 & 3,30 \\
\hline 10 & $\begin{array}{l}\text { Menyatakan keluhan kepada karyawan BRI } \\
\text { bila bermasalah dengan pelayanan BRI }\end{array}$ & 35,70 & 57,60 & 4,80 & 1,90 & - & 4,27 \\
\hline & Total Rata - Rata & & & & & & 25 \\
\hline
\end{tabular}

Sumber Data Penelitian

Keterangan : SS (Sangat Setuiu), S (Setuiu), KS (Kurang Setuiu), TS`(Tidak Setuiu) dan STS (Sangat Tidak Setuiu)

Program Studi Magister Manajemen Program Pascasarjana

Universitas Syah Kuala Nangroe Aceh Darussalam 
Dilihat dari tabel 5 diatas persepsi responden terhadap loyalitas dalam Hubungannya terhadap jasa perbankan PT. Bank Rakyat Indonesia (Persero), Tbk Kota Medan yaitu item dengan skor rata-rata tertinggi adalah item yang menyatakan keluhan kepada karyawan BRI bila bermasalah dengan pelayanan BRI (L35) sedangkan untuk skor rata-rata terendah adalah item dengan pertanyaan saya akan melakukan transaksi lebih sedikit dengan BRI untuk tahuntahun berikutnya (L31). Jika dilihat pada hasil jawaban responden menunjukkan dengan menyatakan keluhan kepada karyawan BRI bila bermasalah dengan pelayanan BRI (L35) menjadi salah satu indikator dalam menentukan kualitas jasa perbankan oleh nasabah yang dilakukan oleh responden.

\section{Uji Reliabilitas Dan Validitas}

Uji keandalan dengan menetapkan nilai patokan 0,05 pada koefisien alpha, artinya suatu instrumen penelitian akan memenuhi tingkat reliabilitas, jika nilai alpha hitung lebih besar dari nilai alpha patokan dan hasil komputasi dapat dilihat pada tabel berikut:

Tabel 6

\section{Hasil Uji Reliabilitas}

\begin{tabular}{ccccc}
\hline Uraian & $\begin{array}{c}\text { Rata-rata } \\
(\text { mean) }\end{array}$ & Jumlah item & Alpha & Keterangan \\
\hline Kualitas & 3,8503 & 25 & 0,920 & Valid \\
Loyalitas & 3,5248 & 10 & 0,536 & Valid
\end{tabular}

Sumber: Data Primer, 2006 (diolah) 


\section{Hasil Uji Reliabilitas}

Berdasarkan tabel hasil uji reliabilitas, ternyata variabel kualitas mempunyai nilai alpha sebesar 0,920 . Dengan rata-rata mean sebesar 3,8503 dari 25 indikator, menunjukkan untuk variabel kualitas valid dimana alpha hitung lebih besar dari alpha tabel 0,5. Ini menunjukkan bahwa pada variabel kualitas mempunyai nilai kesahihan yang tinggi, seperti terlihat dari tabel 7 di bawah ini.

Tabel 7

Hasil Uji Reliabilitas Variabel Kualitas

Reliability Statistics

\begin{tabular}{ccc} 
& Cronbach's Alpha & N of Items \\
\hline Kualitas & .920 & 25 \\
\hline
\end{tabular}

Sumber: Data Primer, 2006 (diolah)

Berdasarkan tabel hasil uji reliabilitas, ternyata variabel loyalitas mempunyai nilai alpha sebesar 0,536. Dengan rata-rata mean sebesar 3,5248 dari 10 indikator, menunjukkan untuk variabel loyalitas cukup valid dimana alpha hitung lebih besar dari alpha tabel 0,5. Ini menunjukkan bahwa pada variabel loyalitas mempunyai nilai kesahihan yang cukup tinggi, seperti terlihat dari tabel 8 di bawah ini.

Tabel 8

Hasil Uji Reliabilitas Variabel Loyalitas

Reliability Statistics

\begin{tabular}{ccc} 
& Cronbach's Alpha & $\mathrm{N}$ of Items \\
\hline Loyalitas & .536 & 10 \\
\hline
\end{tabular}

Sumber: Data Primer, 2006 (diolah)

Sedangkan untuk kedua variabel kualitas dan loyalitas diperoleh nilai alpha sebesar 0,781 dengan total rata-rata 7,3750 yang terdapat pada tabel 9. Ini Program Studi Magister Manajemen Program Pascasarjana Universitas Syah Kuala Nangroe Aceh Darussalam 
menunjukkan bahwa kedua variabel tersebut mempunyai nilai kesahihan yang tinggi dan berpengaruh secara signifikan antara kedua variabel tersebut, terutama pada variabel kualitas. Hal ini sesuai dengan penelitian sebelumnya yang di lakukan oleh Cronin, Taylor 1992, Zeithaml, et al., 1996 (dikutip dalam Bloemer, 1998).

Tabel 9

Hasil Uji Reliabilitas Variabel Kualitas dan Loyalitas

Reliability Statistics

\begin{tabular}{ccccc}
\hline $\begin{array}{c}\text { Cronbach's } \\
\text { Alpha }\end{array}$ & Mean & Variance & $\begin{array}{c}\text { Std. } \\
\text { Deviation }\end{array}$ & N of Items \\
\hline $\mathbf{7 8 1}$ & $\mathbf{7 . 3 7 5 0}$ & $\mathbf{. 4 1 5}$ & $\mathbf{. 6 4 4 5 6}$ & $\mathbf{2}$ \\
\hline \multicolumn{5}{c}{ Sumber: Data Primer, 2006 (diolah) }
\end{tabular}

\section{Hasil Uji Validitas}

Dari 35 item yang diuji (terlampir), menunjukkan terdapat dua item yang tidak valid yaitu item 31 dan 34 dengan nilai yang berada dibawah 0,138. Akan tetapi berdasarkan bentuk pertanyaan yang diajukan peneliti kepada responden untuk item 31 dan 34 tersebut adalah pertanyaan yang negatif, maka dapat disimpulkan bahwa walaupun nilai yang diperoleh sebesar $-0,260$ dan 0,047 adalah nilai yang berada dibawah 0,138 tetap menghasilkan validitas bagi kedua item tersebut. Dengan demikian, seluruh item yang diuji adalah valid. Hal ini sesuai dengan penelitian sebelumnya yang di lakukan oleh Zeithaml, et al., 1996 (dikutip dalam Bloemer, 1998) 


\section{Faktor-Faktor Kualitas Jasa Bank}

Telah disebutkan bahwa variabel bebas sebagai faktor Kualitas Jasa terdiri dari lima indikator yakni Tangibles, Reliability, Responsiveness, Assurance dan Empathy yang disajikan berdasarkan masing-masing komponen berikut ini:

a. Tangibles
a. Peralatan modern
b. Fasilitas fisik yang menarik
c. Pekerja berpenampilan rapi
d. Pamflet yang menarik

b. Reliability
a. Menepati janji untuk melakukan keinginan nasabah
b. Menyelesaikan masalah nasabah dengan tulus
c. Melayani nasabah dengan benar
d. Melayani nasabah sesuai dengan waktu yang dijanjikan
e. Mempunyai kebijakan untuk menghindari kesalahan

c. Responsiveness
a. Memberitahukan nasabah waktu pelayanan
b. Pelayanan yang cepat dan tepat
c. Berkeinginan untuk membantu nasabah
d. Meluangkan waktu untuk menanggapi keluhan nasabah

d. Assurance

a. Pekerja yang mempunyai keterampilan dan pengetahuan yang diperlukan

b. Sopan, hormat, perhatian dan ramah kepada nasabah 
c. Memberi rasa percaya dan kejujuran pada nasabah

d. Memberi rasa aman pada nasabah untuk bertransaksi

e. Empathy
a. Kemudahan untuk mendekati dan menghubungi nasabah
b. Memberi informasi yang mudah dimengerti nasabah
c. Mengetahui kebutuhan khusus nasabah

\section{Faktor-Faktor Loyalitas Nasabah}

Variabel terikat sebagai faktor loyalitas nasabah terdiri dari beberapa komponen seperti berikut :

a. Nasabah selalu mengatakan hal positif mengenai BRI kepada orang lain

b. Nasabah merekomendasikan BRI kepada orang lain

c. Nasabah menyarankan BRI kepada orang lain

d. Nasabah mempertimbangkan BRI sebagai pilihan pertama

e. Nasabah melakukan transaksi lebih banyak di BRI

f. Nasabah tidak akan berpindah ke Bank lain selain BRI

\section{Uji Hipotesis}

Paket SPSS versi 14.00 digunakan untuk menguji ke atas hipotesis yang sudah dinyatakan sebelumnya.

Berdasarkan analisis data dengan menggunakan korelasi maka diperoleh output sebagai berikut : 
Tabel 10

Korelasi Bivariat

Correlations

\begin{tabular}{llcr}
\hline & & Kualitas & \multicolumn{1}{c}{ Loyalitas } \\
\hline Kualitas & Pearson & 1 & $.651(* *)$ \\
& Correlation & & .000 \\
& Sig. (2-tailed) & & 210 \\
\hline N & Pearson & $.651(* *)$ & 1 \\
& Correlation & .000 & \\
& Sig. (2-tailed) & 210 & 210 \\
& N & & \\
** Correlation is significant at the 0.01 level (2-tailed). &
\end{tabular}

Probabilitas atau signifikan 0,000 lebih kecil dari 0,05. Hal ini berarti

Ho ditolak atau dengan kata lain hubungan antara kualitas dan loyalitas pada objek penelitian adalah sangat erat. Hal ini sesuai dengan penelitian sebelumnya yang di lakukan oleh Cronin, Taylor 1992, Zeithaml, et al., 1996 (dikutip dalam Bloemer, 1998). Hasil analisis ini juga dapat didukung dengan tabel berikut :

Tabel 11

Korelasi Nonparametrik

\section{Correlations}

\begin{tabular}{rrlrr}
\hline & & Kualitas & Loyalitas \\
\hline Spearman's rho & Kualitas & Correlation & 1.000 & $.611(* *)$ \\
& & Coefficient & & .000 \\
& Sig. (2-tailed) &. & 210 \\
\hline & N & 210 & 1.000 \\
& Loyalitas & Correlation & $.611(* *)$ & \\
& & Coefficient & .000 & 210 \\
& Sig. (2-tailed) & 210 & 2 \\
& $\mathrm{~N}$ & & \\
\hline
\end{tabular}

** Correlation is significant at the 0.01 level (2-tailed).

Sumber: Data Primer, 2006 (diolah) 
Jadi, dari kedua hasil analisis di atas, dapat dikatakan bahwa terdapat hubungan yang signifikan antara kualitas dan loyalitas nasabah jasa perbankan PT. Bank Rakyat Indonesia (Persero), Tbk Kota Medan. 


\section{BAB V}

\section{KESIMPULAN DAN SARAN}

\section{Kesimpulan}

Dari hasil pembahasan penelitian ini dapat ditarik beberapa kesimpulan sebagai berikut:

1. Instrumen dalam penelitian ini berjumlah 210 angket untuk mendapatkan data yang berhubungan dengan kualitas dan loyalitas nasabah jasa perbankan PT. Bank Rakyat Indonesia (Persero), Tbk Kota Medan. Data yang diperoleh adalah valid dan dapat dipercaya dengan persyaratan statistik yang telah ditetapkan. Hal ini dapat dilihat dari nilai sebesar 0,920 untuk reliabilitas variabel kualitas dan 0,536 untuk variabel loyalitas. Demikian juga secara keseluruhan data dinyatakan valid yang terdapat pada tabel 4,5,6 dan 7 untuk masing-masing variabel kualitas dan loyalitas.

2. Hasil penelitian mengenai karakteristik sosial responden menunjukkan bahwa angket dibagikan secara merata kepada laki-laki ataupun perempuan dengan tingkat perbedaan sebesar $5 \%$ diantaranya dan kebanyakan sudah berkeluarga (55,2\%). Mayoritas responden berusia 20 - 30 tahun $(46,7 \%)$ dengan tingkat pendidikan terakhir sarjana $(41,4 \%) .30,5 \%$ dari seluruh responden bekerja sebagai Pegawai Negeri Sipil (PNS) yang merupakan jumlah terbanyak dari jenis pekerjaan lain yang diajukan pada angket. Jumlah mayoritas pendapatan responden diperoleh berkisar Rp. 501.000,- s/d Rp. 1.500.000,- dengan persentase 48,1 , sedangkan responden yang banyak bertransaksi di bank ini adalah Warga Negara Indonesia (WNI) sebesar 96,7\% walaupun sebenarnya 
tidak tertutup bagi WNI Keturunan untuk turut bertransaksi yang diperlihatkan pada $3,3 \%$ dari seluruh responden.

3. Persepsi responden terhadap kualitas dalam kaitannya terhadap jasa perbankan PT. Bank Rakyat Indonesia (Persero), Tbk Kota Medan Item dengan skor ratarata tertinggi adalah item karyawan berpenampilan rapi (K3) sedangkan untuk skor rata-rata terendah adalah item karyawan selalu ingin tahu nasabahnya (K16), jika dilihat pada hasil jawaban responden menunjukkan dengan karyawan berpenampilan rapi (K3) menjadi salah satu indikator dalam menentukan kualitas jasa perbankan oleh nasabah yang dilakukan oleh responden.

4. Persepsi responden terhadap loyalitas dalam kaitannya terhadap jasa perbankan PT. Bank Rakyat Indonesia (Persero), Tbk Kota Medan Item dengan skor rata-rata tertinggi adalah item Menyatakan keluhan kepada karyawan BRI bila bermasalah dengan pelayanan BRI (L35) sedangkan untuk skor rata-rata terendah adalah item Saya akan melakukan transaksi lebih sedikit dengan BRI untuk tahun-tahun berikutnya (L31), jika dilihat pada hasil jawaban responden menunjukkan dengan Menyatakan keluhan kepada karyawan BRI bila bermasalah dengan pelayanan BRI (L35) menjadi salah satu indikator dalam menentukan kualitas jasa perbankan oleh nasabah yang dilakukan oleh responden.

5. Kontribusi semua faktor yang diteliti menunjukkan adanya hubungan yang signifikan antara kualitas dan loyalitas nasabah jasa perbankan PT. Bank Rakyat Indonesia (Persero), Tbk Kota Medan. Hal ini diperoleh dengan menggunakan uji korelasi bivariat dengan hasil 0,000 yaitu nilai yang berada 
dibawah 0,05. Jadi, secara keseluruhan terdapat hubungan signifikan antara kedua variabel tersebut (kualitas dan loyalitas).

6. Hasil penelitian memperlihatkan bahwa koefisien korelasi antara variabel kualitas dan loyalitas sebesar 0,611 yang berarti bahwa terdapat hubungan diantara kedua variable tersebut. Hal ini juga dapat dilihat dari korelasi pearson diantara kedua variabel tersebut dengan tingkat hubungan sebesar 0,651. Jadi secara keseluruhan hasil penelitian ini memperlihatkan adanya hubungan yang signifikan antara variabel kualitas dan loyalitas nasabah jasa perbankan PT. Bank Rakyat Indonesia (Persero), Tbk Kota Medan.

\section{Saran}

Adapun yang menjadi saran peneliti berdasarkan hasil penelitian yang sudah dianalisis adalah :

1. Secara keseluruhan apa yang sudah dilakukan PT. Bank Rakyat Indonesia (Persero), Tbk Kota Medan kepada nasabah sudah baik. Hal ini diketahui dari hasil analisis yang didapat dari frekuensi dan persentase variabel kualitas dimana dari 210 responden dari jawaban menyatakan setuju dengan persentase yang terbanyak dengan rata-rata 3,8503 dari 25 item adalah Perusahaan memberikan solusi apabila saya menghadapi masalah $(76,70 \%)$, Perusahaan mengutamakan pelayanan $(73,30 \%)$, Perusahaan tanggap dalam menyelesaikan permasalahan operasional transaksi perbankan $(74,80 \%)$, Karyawan selalu berupaya untuk membantu saya $(73,30)$, Karyawan mempunyai pengetahuan yang mendalam untuk menjawab pertanyaan nasabah $(74,30 \%)$, Perusahaan selalu menanamkan keyakinan pada nasabah 
(71,90 \%) yang menggambarkan kualitas terhadap jasa perbankan. Dengan demikian dari survey yang dilakukan peneliti terhadap responden perlu dipertahankan dan ditingkatkan di masa akan datang adalah Perusahaan sigap dalam mengatasi segala permasalahan, mengutamakan pelayanan terhadap nasabah, pekerja selalu berupaya membantu nasabah, perbaikan di bidang operasional yang cepat dan tepat dan meningkatkan kemampuan SDM mengingat persaingan yang semakin ketat di dunia perbankan khususnya di kota Medan.

2. Berdasarkan masalah tersebut di atas, maka PT. Bank Rakyat Indonesia (Persero), Tbk Kota Medan perlu memperhatikan dan meningkatkan lagi sikap karyawan terhadap nasabah misalnya keramahan, senantiasa membantu nasabah dan mengetahui keinginan nasabah agar nasabah mau merekomendasikan Bank ini kepada orang lain seperti teman, keluarga, kenalan dan lainnya. Apabila semakin banyak nasabah dan seringnya bertransaksi dengan BRI, maka akan memperlihatkan kualitas layanan bank ini semakin baik. Hal ini diketahui dari hasil analisis yang didapat dari frekuensi dan persentase variabel loyalitas dimana dari 210 responden menyatakan setuju dengan persentase yang terbanyak dengan rata-rata 3,5248 terhadap 10 item yang menggambarkan loyalitas terhadap jasa perbankan.

3. Pengetahuan dan penampilan rapi yang dituntut dari karyawan juga perlu ditingkatkan lagi supaya nasabah tidak meluangkan waktu yang cukup banyak untuk menunggu permasalahannya selesai. Dengan demikian apabila semua hal di atas terpenuhi maka nasabah akan lebih banyak dan lebih sering 
melakukan transaksi pada PT. Bank Rakyat Indonesia (Persero), Tbk Kota Medan. 


\section{DAFTAR KEPUSTAKAAN}

Anderson, E.W., and Fornell, C. (1996), "A customer satisfaction research prospectus" in Rust, R.T. and Oliver, R.L. (Eds), Service Quality : New Directions in Theory and Practice, Sage Publications, Thousand Oaks, CA, pp. $241-68$

Bansal, H.S. and Taylor, S.F. (1999), "The Service Provider Switching Model (SPSM) : A Model of Consumer Switching Behavior in the Services Industry", Journal of Service Research, Vol. 2, pp. 200-18

Bellenger, D.N, Steinberg, E. and Stanton, W. (1976), "The congruente of store image and self image as it relates to store loyalty", Journal of Retailing, Vol. 52, pp. 17-32

Berry, L.L., Parasuraman A, Zeithaml, V. A. The Service Quality Puzzle. Bus Horizons 1988; $31(5): 35-43$

Bitner, M.J. and Hubbert, A.R. (1994), "Encounter satisfaction versus overall satisfaction versus quality : The customer's voice", in Rust, R.T. and Oliver, R.L. (Eds), Service Quality : New Directions in Theory and Practice, Sage Publications, Thousand Oaks, CA, pp. 72-94

Bloemer. Josee, Ko De Ruyter and Martin Wetzels (1998), "Linking Perceived Service Quality And Service Loyalty : A Multi-Dimensional Perspective", European Journal of Marketing, Vol. 33, pp.1082 - 1106

Cheverton. Peter, (2003), “How Come You Can't Identify Your Key Customers?", Penerbit Elex Media Komputindo, Edisi Pertama

Chip R. Bell and Bilijack R. Bell (2004), "Magnetic Service”, Penerbit Mizan Pustaka, Edisi Pertama

Crosby, L.A., Evans, K. and Lowles, D. (1990), "Relationship quality in services selling : an interpersonal influence perspective", Journal of Marketing, $\quad$ Vol. $\quad 54, \quad$ pp. 68-81

Czepiel, J.A. (1990), "Managing relationships with customers : a differentiation philosophy of marketing", in Bowen, D.E., Chase, R.B.and Cummings, T.G.(Eds), Service Management Effectiveness, Jossey. Bass Publishers, San Fransisco, C.A, pp. 299-323

Czepiel, J.A. and Gilmore, R. (1987), "Exploring the concept of loyalty in services", in Czepiel, J.A., Congram, C.A. and Shanahan, J. (Eds), The Services Marketing Challenge : Integrating for Competitive Advantage, AMA, Chicago, IL, pp. 91-4

Program Studi Magister Manajemen Program Pascasarjana

Universitas Syah Kuala Nangroe Aceh Darussalam 
Dick, A.S and Basu (1994), "Customer Loyalty : toward an integrated conceptual framework", Journal of the Academy of Marketing Science, Vol. 22, pp. 99-113

Dwyer, F.R., Schurr, P.H. and Oh, S. (1987), "Developing buyer-seller relationships", Journal of Marketing, Vol. 51, pp. 11-27

Engel, James F (1994). Perilaku Konsumen, Bina Rupa Aksara Jakarta.

McDougall, G.H., and Terence J. Levesque (1994), "Benefit Segmentation using Service Quality Dimensions : An Investigation in Retail Banking", International Journal of Bank Marketing, Vol. 12, pp. 15 - 23

Gremler, D.D. and Brown, S.W. (1996), "Service loyalty", its nature, importance and implications", in Edvardsson, B.Brown, S.W., Johnston, R. and Scheuing. E (Eds), QUIS V : Advancing Service Quality : A Global Perspective, ISQA, New York, NY, pp. 171-81

Griffin. Jill, (2003), “Customer Loyalty “, Penerbit Erlangga, Edisi Revisi Dan Terbaru

Gronroos, C. (1984), Strategic Management and Marketing in the Service Sector, Chartwell-Brau. London

Guiltinan, J.P. (1989), “A classification of switching costs with implications for relationship marketing", in Childers, T.L. and Bagozzi, R.P. (Eds), AMA Winter Educators' Conference: Marketing Theory And Practice, AMA, Chicago, IL, pp. 216-20

Jacks. Rod Devey Anthony, (2003) How To Be Better at Marketing, Cetakan kedua PT. Elex Media Komputindo Kelompok Gramedia - Jakarta.

Jacoby, J. and Chestnut, R.W. (1978), Brand Loyalty: Measurement and Management, John Wiley \& Sons, New York, NY

James, Don L., Richard M. Durand, and Robert A. Dreves. (1975, Summer). The Use of a Multi-Attribute Model in a Store Image Study. Journal of Retailing, $52: 23$ - 32

Keaveney, S.M. (1995), "Customer Switching behaviour in service industries : an exploratory study", Journal of Marketing, Vol. 59, pp. 71-82

Klemperer, P. (1987), "Markets with consumer switching costs", The Quarterly Journal of Economics, Vol. 102, pp. 375-94 
Kotler, Philip. (1995) Manajemen Pemasaran. Analisis, Perencanaan, Implementasi dan Pengendalian. Jilid Satu dan Dua, Edisi Delapan, Salemba Empat, Jakarta.

Kotler, Philip. (1997) Manajemen Pemasaran, Analisis, Perencanaan, Implementasi dan Kontrol, Jilid Dua, Edisi Revisi, Prenhallindo, Jakarta.

Lee, B.A. and Zeiss, C.A. (1980), "Behavioral commitment to the role of sport consumer ; an exploratory analysis", Sociology and Social Research, Vol.64, pp. 405-19

Lewis. Barbara R, Jayne Orledge and Vincent Wayne Mitchell (1994),"Service Quality : Students' Assessment of Bank and Building Societies", International Journal of Bank Marketing, Vol. 12, pp. 3 - 12

Liljander, V. and Strandvik, T. (1995), "The nature of customer relationships in services", in Swartz, T.A., Bowen, D. and Brown, S.W. (Eds), Advances in Services Marketing Management, Vol. 4, pp. 141-67

Macintosh, G. and Lockshin, L.S. (1998), "Retail relationships and store loyalty", a multilevel perspective", International Journal of Research in Marketing, Vol. 14, pp. 487-98

Malhotra, N.K. (1996). Marketing Research : An Aplied Orientation. $2^{\text {nd }} \cdot$ Ed. New Jersey : Prentice - Hall internasional, Inc.

Ma'ruf, J.J., Ramayah, T., Mohamad, O., Lubis, A. R., (2005). Pengembangan model pengukuran untuk memprediksi perilaku niat menggunakan internet untuk membeli : Suatu pendekatan structural equation model, The proceedings of the International Seminar, Indonesia-Malaysia, Banda Aceh, Indonesia, $14-15^{\text {th }}$ October 2002

Mason. Robert D, Douglas A. Lind (1996) Tehnik Statistik Untuk Bisnis dan Ekonomi, Jilid Satu Erlangga

Mowen. John C, (1995). Consumer Behavior. Fouth Edition Practice Hall International Edition, Oklahoma State Universiti

Newman, J.W. and Werbel, R.A. (1973), "Multivariate analysis of brand loyalty for major household appliances", Journal of Marketing Research, Vol. 10, pp. 404-9

Niels Peter Mols (2000), “ The Internet and Services Marketing - The Case of Danish Retail Banking “, Internet Research : Electronic Networking Applications and Policy, Vol. 10, pp.7 - 18

Nunnaly, Jum C, and Bernstein, Ira, H : Psychometric Theory, $3^{\text {rd }}$ Edition McGraw-Hill Book Company, New York, 1994

Program Studi Magister Manajemen Program Pascasarjana

Universitas Syah Kuala Nangroe Aceh Darussalam 
Ostrowski, P.L., O'Brien, T. and Gordon, G. (1993), "Service quality and customer loyalty in the comercial airline industry", Journal of Travel Research, Vol. 32, pp. 16-24

Parasuraman A, Zeithaml, V.A and Berry, L.L : A Conceptual Model of Service Quality and Its Implications for Future Research. Journal of Marketing $49,41-50(1985)$

Parasuraman, A., Zeithaml, V. A and Berry, L.L. (1988), "SERVQUAL : a multiple-item scale for measuring consumer perceptions of service quality “, Journal of Retailing, Vol. 67, pp. 420-50

Rangkuti. Freddy, (2003). Riset Pemasaran, Cetakan Enam, PT. Gramedia Pustaka Utama, Jakarta.

Sewel, Carl dan Paul B. Brown. (1990) The Golden Rules Of Costumer Care. Bussiness Book Ltd xx, London.

Snyder, D.R. (1986), "Service loyalty and its measurement : a preliminary investigation", in Venkatesan, M., Schmalensee, D.M. and Marshall, C. (Eds), Creativity in Service Marketing : What's New, What Works, What's Developing, AMA, Chicago, IL, pp. 44-8

Spiggle, Susan and Murphy A. Sewall. (1987, April). A Choice sets Model of Retail Selesction. Journal of Marketing, 51 : 97 - 111

Storbacka, K., Strandvik, T. And Gronroos, C. (1994), "Managing customer relationships for profit the dynamics of relationship quality", International Journal of Service Industry Management, Vol. 5, pp. 21-38

Sudman, S., and Bradburn, N.M.: Asking Questions : A Practical Guide to Questionnaire Design. Josey - Bass Publishers, San Fransisco, 1983

Suprapto. J, (2002). Metode Riset, Edisi ketujuh Rineka Cipta, Jakarta

Surprenant, C.F and Solomon, M.R. (1987), "Predictability and personalization in the service encounter", Journal of Marketing, Vol. 51, pp. 86-96

Taylor, S.A. and Baker, T.L. (1994),"An Assessmant of the relationship between service quality and customer satisfaction in the formation of consumers' purchase intentions", Journal of Retailing, Vol. 70, pp. 16378

Tsiros. Michael, Vikas Mittal, William T. Ross Jr (2004), "The Role of Attribution Customer Satisfaction : A Reexamination", Journal of Consumer Research, Vol. 31, pp. $476-483$

Program Studi Magister Manajemen Program Pascasarjana

Universitas Syah Kuala Nangroe Aceh Darussalam 
Tucker, W.T. (1964, August). The Development of Brand Loyalty. Journal of Marketing Research, $32-35$

Umar. Husein, (2003) Metode Riset Bisnis. PT. Gramedia Pusaka Utama Jakarta

Zeithaml, V.A. (1981), "How consumer evaluation processes differ between goods and services", in Donnelly, J.H. and George, W.R. (Eds), Marketing of Services, AMA, Chicago, IL, pp. 186-90

Zeithaml, V.A., Berry, L.L. and Parasuraman, P. (1988), "Communication and Control Processes in the Delivery of Service Quality", Journal of Marketing, Vol. 52, April, pp. 35-48

Zeithaml, V.A. and Bitner, M.J. (1996), Services Marketing, McGraw-Hill, New York, NY 